\title{
KEBERHASILAN PEMBERDAYAAN EKONOMI MASYARAKAT DALAM EKSPOR KERAJINAN SANGKAR BURUNG
}

\author{
Dyah Kuntorini Dwi Angreni $^{1}$, Sulikah Asmorowati \\ ${ }^{1,2}$ Universitas Airlangga \\ 1dyah.kuntorini.dwi-2019@fisip.unair.ac.id, ${ }^{2}$ sulikah.asmorowati@fisip.unair.ac.id
}

Diterima: Agustus 2020; Disetujui: Maret 2021

\begin{abstract}
Bird cage craft is a economy creative effort that utilizes local potential as well as hone abilities and skills. Bird cage made of wood with added carvings. The management of bird cage crafts is able to improve the economy of the residents of Gedog Wetan Village, Turen District, Malang Regency. Able to produce super quality with marketing outside Java and even export to Mexico. The research approach carried out by the researcher is a type of qualitative research. The research objective is to describe the empowerment of the community in managing bird cage crafts and the impact on improving the economy of the community of Gedog Wetan Village. The economic empowerment of village communities in making bird cages has good future prospects so that it can become a characteristic of the village and be able to prosper the economy of the village community. The proposed model was approved and has been applied to next year's government budget as a pilot project with the support of various stakeholders. It is hoped that this model will be able to accelerate rural economic development and the expansion of handicraft businesses that are managed in a sustainable manner.
\end{abstract}

Keywords: craft, economy, empowerment, village.

Abstraksi. Kerajinan sangkar burung adalah usaha ekonomi kreatif yang memanfaatkan potensi lokal juga mengasah kemampuan dan ketrampilan. Sangkar burung yang terbuat dari bahan kayu dengan tambah hiasan ukiran. Pengelolaan kerajinan sangkar burung mampu meningkatkan perekonomian warga Desa Gedog Wetan Kecamatan Turen, Kabupaten Malang. Mampu memproduksi kualitas super dengan pemasaran sudah luar Jawa bahkan mampu ekspor ke Meksiko. Pendekatan penelitian yang dilakukan peneliti adalah jenis penelitian kualitatif deskriptif. Tujuan penelitian adalah mendeskripsikan tentang pemberdayaan masyarakat dalam mengelola kerajinan sangkar burung dan dampak terhadap peningkatan perekonomian masyarakat Desa Gedog Wetan. Pemberdayaan ekonomi masyarakat desa dalam pembuatan sangkar burung sudah memiliki prospek ke depan yang bagus hingga mampu menjadi ciri khas desa dan mampu menyejahterakan perekonomian masyarakat desa. Penting untuk diteliti karena model yang telah diusulkan disetujui dan sudah diterapkan untuk anggaran pemerintah tahun depan sebagai percontohan proyek dengan dukungan berbagai pemangku kepentingan. Diharapkan model tersebut mampu mempercepat pembangunan ekonomi pedesaan, dan perluasan usaha kerajinan yang dikelola secara berkelanjutan.

Kata kunci: desa, ekonomi, kerajinan, pemberdayaan.

\section{PENDAHULUAN}

Pemerintahan desa sebagai unit lembaga pemerintahan yang paling berdekatan dengan masyarakat, posisi dan kedudukan hukumnya hingga saat ini menjadi perdebatan terutama di tingkat elit politik. Pemerintahan desa memiliki peranan signifikan dalam proses sosial. Pemerintah desa merupakan sub sistem dari sistem penyelenggaraan pemerintah, sehingga desa 
memiliki kewenangan untuk mengatur dan mengurus kepentingan masyarakatnya. Kepala Desa bertanggung jawab kepada Badan Perwakilan Desa dan menyampaikan laporan pelaksanaan tersebut kepada Bupati. Sesuai dengan ketentuan yang berlaku Pasal 18 Undang-Undang Nomor 6 Tahun 2014 memberikan kewenangan desa meliputi di bidang penyelenggaraan, pemerintah desa, pelaksanaan pembangunan desa, pembinaan kemasyarakatan desa, dan pemberdayaan masyarakat desa berdasarkan prakarsa masyarakat, hak asal usul, dan adat istiadat desa.

Membahas pemberdayaan masyarakat desa yang mengacu pada proses perubahan struktural masyarakat dengan pendekatan baru dan lebih baik agar masyarakat mampu memenuhi kebutuhan dasar dan sosialnya secara layak. Penulis mengartikan pemberdayaan masyarakat desa ini merupakan sebuah upaya untuk meningkatkan keberdayaan masyarakat, baik secara sosial ekonomi, kebudayaan, dan politik, sehingga mampu untuk mengakses berbagai sumber daya yang ada. Selain itu dengan tujuan untuk meningkatkan kesadaran kritis masyarakat, sehingga mampu melaksanakan pengawasan terhadap implementasi sebuah peraturan. Sesuai dengan Undang-Undang 6 Tahun 2014 Pasal 1 ayat 12, Pemberdayaan Masyarakat Desa adalah upaya mengembangkan kemandirian dan kesejahteraan masyarakat dengan meningkatkan pengetahuan sikap, keterampilan, perilaku, kemampuan, kesadaran, serta memanfaatkan sumber daya melalui penetapan kebijakan, program, kegiatan, dan pendampingan yang sesuai dengan esensi masalah dan prioritas kebutuhan masyarakat desa.
Dalam konteks permasalahan sederhana, ekonomi rakyat merupakan strategi "bertahan hidup" yang dikembangkan oleh penduduk masyarakat miskin, baik di kota maupun di desa-desa. Meningkatkan kesejahteraan, merupakan kegiatan ekonomi dalam pemberdayaan di masyarakat. Ekonomi dapat diartikan sebagai upaya dalam mengelola rumah tangga. Tujuannya adalah untuk memenuhi kebutuhan hidup melalui tiga kegiatan utama yaitu: produksi, distribusi, dan konsumsi. Pemenuhan hidup dengan kendala terbatasnya sumber daya, erat kaitannya dengan upaya meningkatkan kemakmuran dan kesejahteraan. Tiga tujuan penting pembangunan ekonomi adalah ditegaskan (Blair, 2010) sebagai berikut pertama mencapai standar hidup minimum, kedua menipisnya ketimpangan, dan ketiga mendorong keberlanjutan.

Produksi, distribusi, dan konsumsi, merupakan rangkaian kegiatan yang berlangsung secara terus menerus dan sering disebut sebagai proses yang berkesinambungan. Proses ini berjalan secara alamiah sejalan dengan perkembangan masyarakat dibidang sosial, ekonomi, budaya dan politik. Secara ekonomi, proses alamiah yaitu bahwa yang menghasilkan (produksi) harus menikmati (konsumsi), dan sebaliknya yang menikmati harus yang menghasilkan. Dengan demikian pemberdayaan ekonomi masyarakat adalah kegiatan ekonomi yang dilakukan oleh masyarakat dengan secara swadaya mengelola sumber daya apapun yang dapat dikuasainya, dan ditunjukkan untuk memenuhi kebutuhan dasarnya dan keluarganya.

Pengusaha adalah orang yang memilih atau menanggung risiko, mengidentifikasi peluang bisnis, mengumpulkan sumber daya, memulai tindakan, dan mendirikan 
organisasi atau perusahaan untuk memenuhi permintaan atau peluang pasar tersebut (Blair, 2010) Dari definisi ini, wirausahawan dipandang sebagai individu mandiri yang mau tenggelam atau berenang dengan idenya. Dengan demikian dapat dikatakan bahwa pengusaha adalah orang yang dalam usahanya bertahan hidup menghasilkan keuntungan dan memiliki usaha sendiri (D, 2016). Secara efektif menggunakan kemampuan dan potensinya dengan percaya diri. Dia mengambil risiko, fokus dan diberi energi oleh dorongan batin. Selain itu sama-sama mencari dan memanfaatkan peluang kerja, menerapkan kreativitas secara agresif, mengambil inisiatif saat ia mencari peluang pasar.

Konsep pemberdayaan ekonomi mulai muncul selama revolusi industri, sekitar abad ke-18, kapan industrialisasi menciptakan produksi komunitas penguasa faktor dan masyarakat yang dikendalikan pekerja. Di negara berkembang, pemberdayaan muncul ketika pembangunan sampai taraf tertentu telah menciptakan ekonomi ketidaksetaraan, degradasi sumber daya alam, dan keterasingan publik dari faktor produksi oleh penguasa (Pradono et al., 2016). Pemberdayaan ekonomi tercapai jika standar hidup dapat dipertahankan dan ditingkatkan melalui proses dan pembangunan fisik yang didasarkan pada prinsip keadilan dan keberlanjutan. Akar masalah biasanya ditemukan sebagai kendala struktural menghalangi kemampuan masyarakat untuk berpartisipasi dalam perekonomian. Pendekatan top down biasanya dilakukan untuk meningkatkan ekonomi pemberdayaan masyarakat melalui perubahan struktural tersebut sebagai alokasi sumber daya, pembangunan dan penguatan kelembagaan, teknologi, dan pengembangan sumber daya manusia
(Blair, 2010). Pendidikan sebagai Pemberdayaan: Menegakkan Hak dan Membangun Komunitas, "seruan untuk bertindak dengan mengklaim bahwa pendidikan adalah kunci dalam memerangi kemiskinan. Penulis membuat kasus ini dengan menekankan pada penerapan hak fundamental atas pendidikan oleh hukum dan kebutuhan untuk menegakkannya (Quarterly, 2015). Pemberdayaan (B-BBEE) (The Codes) dikukuhkan sebagai program untuk mengemudi transformasi, seperti yang dirangkum dalam dari $B$-BBEE Act Pemberdayaan Ekonomi diperkenalkan untuk mencakup lebih banyak bidang ekonomi (Forbes \& Rust, 2019). The blueprints, melalui kerangka kebijakan, juga menantang konvensional berpikir di balik partisipasi, pemberdayaan dan pendekatan berbasis masyarakat, yang sering kali menyalahkan miskin karena menjadi miskin dan menempatkan tanggung jawab untuk pengentasan kemiskinan pada mereka (Hyle et al., 2019).

Konsep di atas semuanya menunjukkan bahwa pemberdayaan ekonomi masyarakat dapat dilihat sebagai proses perubahan dari situasi kekuasaan yang kurang ke keadaan yang lebih mampu mengontrol dan untuk meningkatkan kehidupan dan takdir komunitas. Transisi ini diperlukan keadaan tertentu yang dapat dimainkan oleh semua pemangku kepentingan peran yang sesuai.

Desa Gedog Wetan merupakan salah satu desa yang berada di Kecamatan Turen Kabupaten Malang. Desa ini terkenal dengan daerahnya yang menjadi sentra kerajinan sangkar burung. Penduduk di Desa Gedog Wetan berusaha membuat sebuah kerajinan yang sederhana tetapi memiliki nilai jual tinggi dengan bahan yang mudah ditemukan. Jumlah pengrajin sekitar ada 100 orang. Dengan kemampuan 
dan ketrampilan yang dimiliki pengrajin, mereka berusaha membuat inovasi-inovasi baru untuk menghasilkan berbagai bentuk kerajinan yang unik dan diminati oleh konsumennya. Masyarakat Desa Gedog Wetan mayoritas warganya adalah wirausaha. Dengan keterampilan yang masyarakat miliki, mempunyai kesempatan untuk mengasah keterampilan mereka dibidang kerajinan khususnya kerajinan sangkar burung dalam upaya meningkatkan pendapatan ekonomi. Dengan adanya kerajinan sangkar burung ini akan dapat menyerap tenaga kerja dari masyarakat setempat dan akan dapat meningkatkan pendapatan masyarakat, serta manfaat lainnya dari pengembangan desa dapat mengurangi pengangguran dan meningkatkan kesejahteraan rakyat. Tujuan penelitian adalah mendeskripsikan tentang pemberdayaan masyarakat dalam mengelola kerajinan sangkar burung dan dampak terhadap peningkatan perekonomian masyarakat Desa Gedog Wetan.

\section{METODE PENELITIAN}

Metode yang digunakan dalam penelitian ini adalah pendekatan kualitatif yang mana bertujuan untuk memahami fenomena sosial secara holistik. Strategi yang digunakan dalam penelitian ini adalah deskriptif. Metode penilaian yang digunakan di Penelitian ini merupakan studi pustaka (literatur), analisis komparatif, survei, observasi dan wawancara.

Pembahasan rinci dilakukan untuk mendapatkan konfirmasi dari pemangku kepentingan. Penelitian ini merupakan bagian dari program penelitian 5 tahun dimana pada tahun bagian ini dimaksudkan untuk mengidentifikasi model ekonomi yang sesuai pemberdayaan bagi masyarakat. Itu dilakukan dalam empat tahapan, yaitu: Tahap persiapan dan penilaian awal, identifikasi dan evaluasi model, pemetaan dan analisis peran pemangku kepentingan, dan perumusan model.

Di setiap fase mengidentifikasi berbagai sudut pandang dari pemangku kepentingan terkait kondisi mereka saat ini. Stakeholder di sini adalah semua aktor yang terlibat dalam industri kerajinan sangkar burung di Desa Gedog Wetan. Serangkaian kunjungan dan pertemuan dengan para pemangku kepentingan dilakukan 3 kali kunjungan lapangan yang telah dilakukan dari tahap awal survei, observasi dan survei, serta Focus Group Discussion (FGD) dilakukan selama kurang lebih $1 \frac{1}{2}$ tahun periode sejak 2018

\section{HASIL DAN PEMBAHASAN}

Kabupaten Malang merupakan daerah yang memiliki potensi besar dalam pengembangan sektor IKM, sebagai berikut:

Tabel 1.

Data IKM Kabupaten Malang

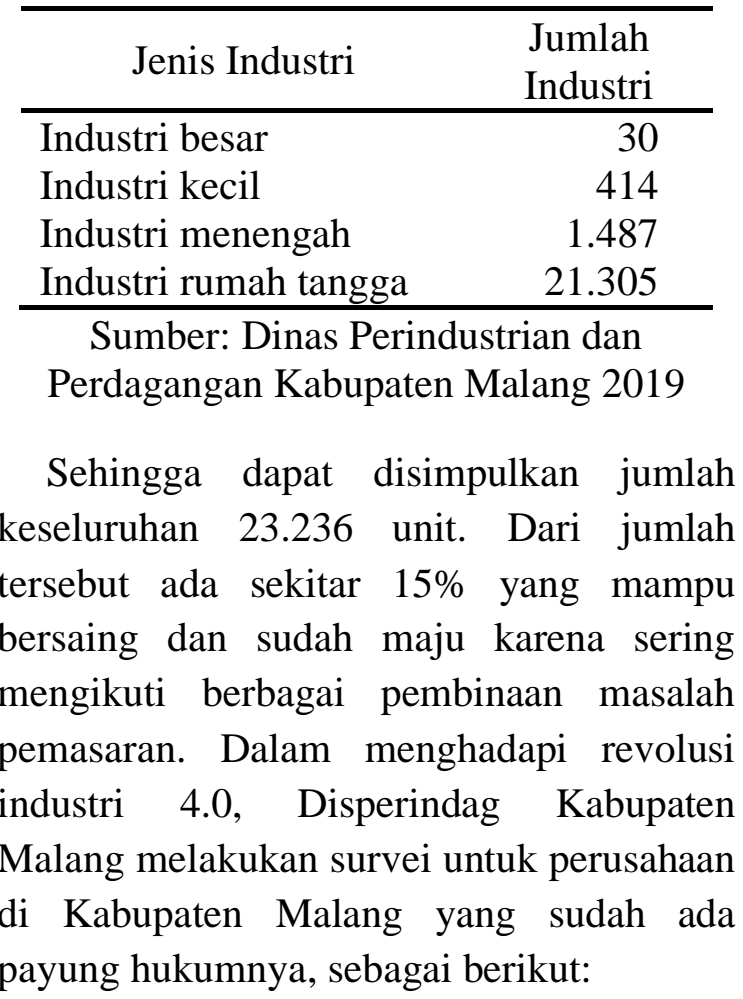


Tabel 2.

Jumlah Perusahaan Menurut Bentuk Badan Hukum di Kabupaten Malang, 2011 - 2018

\begin{tabular}{lrrrrrr}
\hline Tipe Badan Hukum & 2013 & 2014 & 2015 & 2016 & 2017 & 2018 \\
\hline Perseroan Terbatas & 1138 & 1221 & 1379 & 1541 & 1685 & 1745 \\
CV/Firma & 3706 & 3991 & 4300 & 4630 & 4916 & 5086 \\
Koperasi & 470 & 487 & 507 & 519 & 526 & 528 \\
Perorangan & 14151 & 14875 & 15639 & 16274 & 16540 & 16643 \\
Lainnya & 32 & 24 & 25 & 25 & 25 & 25 \\
$\quad$ Jumlah & 19497 & 20598 & 21850 & 22989 & 23692 & 24027 \\
\hline
\end{tabular}

Sumber: Dinas Perindustrian dan Perdagangan Kabupaten Malang 2019

Dengan Industri Kecil dan Menengah (IKM)yang menonjol adalah Industri Kecil dan Menengah (IKM) dari sektor non-agro selain itu juga sudah siap menghadapi revolusi industri 4.0 yaitu dari sektor industri handmade, batik dan logam.

Pembahasan mengenai industri kerajinan sangkar burung ini sangat menarik karena salah satu industri kecil yang siap menghadapi revolusi industri 4.0. Menariknya lagi sektor kerajinan sangkar burung ini menjadi penyumbang ekspor besar di Kabupaten Malang, berikut data ekspor di Kabupaten Malang:

Tabel 3.

Jumlah Ekspor di Kabupaten Malang Tahun 2016-2018

\begin{tabular}{lrrr}
\hline \multicolumn{1}{c}{ Ekspor } & \multicolumn{4}{c}{ Realisasi Ekspor Non Migas } \\
& 2016 & 2017 & \multicolumn{2}{c}{2018} \\
\hline Volume (kg) & $27.932 .161,49$ & $27.766 .3538,84$ & $282.949 .200,82$ \\
Nilai (US \$) & $377.153 .816,14$ & $388.442 .850,00$ & $402.625 .370,63$ \\
Komoditi & 38 & 38 & 38 \\
Tujuan & 73 & 71 & 71 \\
Eksportir & 70 & 70 & 50 \\
(perusahaan) & & & 519 \\
\hline Sumber: Dinas Perindustrian dan Perdagangan Kabupaten Malang 2019
\end{tabular}

Berdasarkan data yang diperoleh penulis dalam kegiatan wawancara serta dokumentasi diperoleh data bahwa kerajinan sangkar burung ini sudah sangat lama diperkirakan tahun 1990-an yang awalnya hobi dari masyarakat yang memelihara burung kemudian timbul keinginan untuk membuat inovasi-inovasi dari sangkar burung yang ada. Desa Gedog Wetan dalam pembuatan sangkar burung awalnya hanya dengan peralatan sederhana dan hanya untuk koleksi pribadi kemudian masyarakat desa lain melihat kualitas sangkar burung yang bagus sejak saat itu desa ini menjadi terkenal. Bisa kita temui mulai harga sangkar burung dari yang paling murah dengan harga Rp 100.000,sampai yang paling mahal seharga jutaan.

Selain itu juga penjelasan yang disampaikan oleh Bapak Sudharsono selaku pengrajin kerajinan sangkar burung berpendapat bahwa: 
"dengan berkembangnya kerajinan sangkar burung yang bisa di distribusikan hingga menguasai pasar luar Jawa bahkan mencapai ekspor Ke Meksiko ini menjadi sebuah kebanggaan dan apresiasi. Selain itu pendapatan masyarakat juga meningkat."

Melihat tingkat kreativitas ini Kepala Desa Gedog Wetan Bapak Budiyono sangat mendukung dengan memberikan alat yang lebih modern dalam pembuatan, agar produksi lebih cepat dengan kualitas lebih bagus, hanya saja kepala desa menyampaikan bantuan alat ini hanya diberikan kepada pengrajin yang menjadi pengepul tempat finishing dimana sudah memiliki nama di distributor terkenal seperti ebod. Selain itu juga faktor setiap pengrajin ini tidak semua membuat sangkar burung tapi dibagi dalam pembuatan kaki sangkar burung, kerangkanya, dan jaringjaring kayu sangkar burung, kemudian dikumpulkan ke pengepul yang akan dilakukan finishing merangkai.

Berangkat dari keinginan masyarakat dan kemampuan yang telah dimiliki untuk melakukan perubahan dan memajukan Desa Gedog Wetan dengan melakukan pemberdayaan masyarakat. Maka melalui perangkat pemerintahan dan peran masyarakat Desa Gedog Wetan bersamasama untuk mengembangkan dan membangun potensi wilayah yang ada di Desa Gedog Wetan bertujuan agar masyarakat bisa mandiri dan dapat meningkatkan kesejahteraan masyarakat. Dalam peningkatan kualitas sangkar burung sudah dilakukan pelatihan dari Disperindag Kabupaten Malang. Mengenai permodalan usaha ini, Desa Gedog Wetan bekerja sama dengan Bank Rakyat Indonesia (BRI). Bahkan desa ini, bukan lagi teras Bank
Rakyat Indonesia (BRI) tapi sudah berupa Unit dari Bank Rakyat Indonesia.

Setelah menjadi pengrajin sangkar burung sudah merasakan manfaatnya yaitu perubahan dalam kesejahteraan, Dengan adanya kerajinan sangkar burung memberikan manfaat kepada masyarakat Desa Gedog Wetan dalam peningkatan ekonomi. Indikator keberhasilan dalam peningkatan ekonomi dengan adanya pemberdayaan masyarakat melalui kerajinan sangkar burung cukup membantu mencukupi kebutuhan keluarga dan biaya sekolah. Sesuai dengan pendapat pengrajin Bapak Sudharsono bahwa :

"Penghasilan untuk pengrajin kecil yang membuat kaki sangkar, kerangka sangkar, jaring - jaring kayu sangkar burung itu mencapai 40-50 ribu setiap harinya, kemudian yang sudah menjadi pengepul memiliki pasar dan distributor terkenal penghasilannya sudah mencapai ratusan juta sehingga bisa membantu memajukan pengrajin yang tergabung. Saya merasa kemajuan desa ini misal dalam hal akses jalan yang sudah bagus dengan masyarakat yang rata - rata mampu"

Selain itu juga pernyataan Bapak Budiyono selaku kepala desa di Desa Gedog Wetan bahwa:

"Kegiatan kerajinan sangkar burung ini harus terus berlanjut di masa mendatang karena saya melihat prospek bagus dari kerajinan ini. Apalagi dengan lebih mengembangkan pemasaran ke luar negeri itu bisa menambah penghasilan lebih besar dan lebih meningkatkan kesejahteraan masyarakat desa ini."

Faktor pendukung dengan adanya pemberdayaan masyarakat melalui usaha kerajinan sangkar burung ini sangat penting 
karena dengan adanya faktor pendukung tersebut kerajinan sangkar burung dapat berjalan dengan optimal, selain itu juga dapat memberdayakan masyarakat Desa Gedog Wetan. Faktor-faktor pendukung dengan adanya usaha kerajinan sangkar burung dalam upaya memberdayakan masyarakat Desa Gedog Wetan terdiri dari beberapa elemen atau unsur yang ada di masyarakat baik alam maupun sumber daya manusianya itu sendiri. Secara garis besar faktor pendukung dengan adanya pemberdayaan masyarakat melalui usaha kerajinan sangkar burung ini berasal dari lingkungan Desa Gedog Wetan yaitu sumber daya manusia, masyarakat, pemerintah dan letak geografis. Maka dari itu harus dilakukan penguatan-penguatan agar dari pendukung yang sudah ada bisa lebih dikembangkan lagi khususnya dengan membina dan memberdayakan masyarakat. Mengenai faktor penghambat adalah masalah cuaca ketika musim hujan produksi menurun karena pengeringan sangkar burung lebih lama untuk dilakukan proses selanjutnya spet dan harga bahan baku kayu yang kadang tidak stabil.

Berdasarkan diskusi intensif dengan pemangku kepentingan, faktor kritisnya dalam mengembangkan model pemberdayaan ekonomi di bidang industri kerajinan di wilayah desa Gedog Wetan telah diidentifikasi. Di antara poin-poin yang disepakati stakeholder adalah partisipasi anggota masyarakat yang lebih intensif, penciptaan lapangan kerja, penciptaan pendapatan, kesetaraan, dan keberlanjutan (Pradono et al., 2016).

Berdasarkan pola interaksi antar komunitas pengrajin, investor, pemerintah sebagai regulator; mode ekonomi yang ada hubungan antar pelaku pengusaha; pemetaan pemangku kepentingan; dan juga arahan dari Pemerintah Pusat, (Deepa
Narayan, n.d.) lalu model pemberdayaan ekonomi diusulkan dan disepakati oleh semua pemangku kepentingan untuk mengoptimalkan manfaat bagi masyarakat dan pelaku usaha.

Pemberdayaan ekonomi melalui Industri Kecil dan Menengah (IKM) Indonesia saat ini menjadi salah satu program nasional sebagai solusi dalam memanfaatkan sumber daya alam mengatasi masalah sosial ekonomi (Badan Pusat Statistik, 2018). Pemberdayaan Ekonomi sektor Industri Kecil dan Menengah (IKM) terjadi dalam berbagai pola bahwa sampai batas tertentu mungkin memerlukan formulasi yang lebih baik.

\section{SIMPULAN}

Berdasarkan penelitian dan pengamatan di lapangan mengenai pelaksanaan pemberdayaan ekonomi masyarakat melalui kerajinan sangkar burung: studi di Desa Gedog Wetan, Turen Kabupaten Malang sebagaimana yang telah diuraikan, maka penulis dapat mengambil kesimpulan : Pemberdayaan ekonomi masyarakat yang dilakukan oleh produsen kerajinan sangkar burung dalam meningkatkan perekonomian masyarakat sekitar dengan mengelola kerajinan sangkar burung adalah pemberdayaan yang mengacu pada membangun dan mengembangkan potensi untuk menyejahterakan masyarakat dari segi ekonomi ataupun sosial. Usaha kerajinan yang sudah mampu di ekspor pemasaran juga sudah bagus. Kesejahteraan masyarakat dari usaha ini sudah terasa dengan rata - rata penduduk Desa Gedog Wetan menengah ke atas.

Berbagai faktor kritis menentukan keberhasilan ekonomi pemberdayaan sektor industri kerajinan di tingkat masyarakat, akan menjadi penting untuk dipertimbangkan dalam implementasi 
model apapun terutama untuk mencapai dan meningkatkan kredibilitas bisnis kerajinan sangkar burung serta dukungan dan penerimaan komunitas lokal. Pemetaan potensi ekonomi dan juga keberadaannya pemberdayaan ekonomi saat ini sebagai langkah pertama untuk mengoptimalkan upaya pemberdayaan. Pengetahuan tentang karakteristik potensi ekonomi masyarakat dan kapasitas masyarakat secara mendalam diperlukan untuk menentukan model pemberdayaan ekonomi di sesuai dengan karakteristik kegiatan ekonomi dan sosial budaya masyarakat di kawasan Desa Gedog Wetan percontohan di wilayah lain.
Penerapan model yang telah diusulkan dimaksudkan untuk menguji keefektifan model di lapangan. Desa Gedog Wetan yang sudah memiliki keunggulan dalam produksi sangkar burung telah dipersiapkan untuk menjadi proyek percontohan model. Komitmen dan koordinasi pemangku kepentingan telah disiapkan. Wujud keberhasilan pengelolaan pemberdayaan ekonomi di Desa Gedog Wetan akan menjadi proyek diidentifikasi untuk evaluasi dan kemungkinan implementasi di wilayah lain.

\section{DAFTAR PUSTAKA}

Badan Pusat Statistik. (2018). Data IKM Disperindag Kabupaten Malang. Malangkab.Bps.Go.Id. from https://malangkab.bps.go.id/subject/9/industri.html\#subjekViewTab1

Blair, J. P. (2010). Book Review: Blakely, E. J., \& Leigh, N. G. (2010). Planning Local Economic Development: Theory and Practice (4th ed.). Thousand Oaks, CA: Sage, 464 pp. \$53.11 (paperback). Economic Development Quarterly, 24(4), 394-395.from https://doi.org/10.1177/0891242410374959

D, A. A. O. P. (2016). an Assessment of Success Made in Local Government Empowerment Programmes and Economic Empowerment of Youth in Ibadan North Local Government Area of Oyo State. 8(1), 12-25.

Deepa Narayan. (n.d.). The Contribution of People's Participation Evidence from 121 Rural Water Supply Project.

Forbes, J., \& Rust, A. B. (2019). Responses of selected enterprises to amended broadbased black economic empowerment legislation. Problems and Perspectives in Management, 17(1), 360-369. from https://doi.org/10.21511/ppm.17(1).2019.31

Hyle, M. A., Devkota, B. P., \& Mustalahti, I. (2019). From blueprints to empowerment of disadvantaged groups in natural resource governance: lessons from Nepal and Tanzania. International Journal of the Commons, 13(2), 1062-1078.from https://doi.org/10.5334/ijc.951

Pradono, P., Faisal, B., Adriani, Y., Rikeu, R., \& Fajriasanti, R. (2016). Towards model of community economic empowerment through tourism activities in Bogor Regency, West Java, Indonesia. International Journal of Economics and Financial Issues, 6(6Special Issue), 46-49.

Quarterly, A. S. (2015). African Studies Quarterly | Volume 15, Issue 4 | September 2015 from http://www.africa.ufl.edu/asq/pdfs/v15i4a5.pdf. 15(4), 101-103. 